\title{
PELVIC INSUFFICIENCY: UNDERDIAGNOSED CONDITION, THERAPEUTIC DIAGNOSTIC REVIEW
}

\author{
INSUFICIÊNCIA PÉLVICA E CONDIÇÃO SUBDIAGNOSTICADA: \\ REVISÃO DIAGNÓSTICA TERAPÊUTICA \\ INSUFICIENCIA PÉLVICA: CONDICIÓN SUBDIAGNOSTICADA, \\ REVISIÓN DIAGNÓSTICA TERAPÉUTICA
}

Francisco Javier Sánchez Garcia ${ }^{1}$, Jorge Alberto de Haro Estrada', Herman Michael Dittmar Johnson ${ }^{1}$

1. Cirugía de Columna Vertebral / Centro Medico Puerta de Hierro / Asociación Civil Re-espalda, Zapopan , Jalisco. México.

\begin{abstract}
Objective: The importance of sacral fractures has recently been recognized. However, its diagnosis is difficult, both clinically and through image, but there are more options for comprehensive diagnosis. Methods: We conducted a literature review about its diagnosis and the treatments currently offered, and also to check which treatments had the best results. Results: Patients with pelvic insufficiency have limited mobility due to lumbar or pelvic pain. As radiculopathy is a neurologically stable condition, it has a reported incidence of only $5 \%$ and sphincter disorders. The pain improves when lying down and increases with load. The treatments vary from conservative to surgical. Discussion: The different treatments were compared, and the one that has more morbidity is the conservative, because it predisposes us to complications (pneumonia, pulmonary embolism, deep vein thrombosis, heart failure, decubitus ulcers); in the interventionists we observe a faster improvement to normal activity of these patients, the complications are minor and the pain improvement is noticeable and much faster. Conclusion: Fractures due to pelvic insufficiency are underdiagnosed. However, there are already better imaging techniques and combined with good exploration and clinical history we can suspect this condition and offer the best possible treatment, these being the invasive ones that have had better results with lower morbidity and recovery of activity much more quickly. Level of Evidence III; Review of therapeutic studies - Investigation of treatment results.
\end{abstract}

Keywords: Fracture; Pelvis; Diagnosis; Therapeutics.

RESUMO

Objetivo: As fraturas por insuficiência pélvica são frequentemente ignoradas nos idosos e nos outros grupos de risco com dor lombar e dor pélvica após um trauma de baixa energia. A importância das fraturas sacrais foi recentemente reconhecida. O diagnóstico é difícil, tanto clinicamente e por imagem, mas há mais opções para o diagnóstico abrangente. Métodos: Uma revisão da literatura sobre o diagnóstico e os tratamentos oferecidos, e qual foi o que teve o melhor resultado. Resultados: Pacientes com insuficiência pélvica apresentam mobilidade limitada, devido a dor lombar aguda ou pélvica, sem evidência de trauma. Neurologicamente estável, a radiculopatia tem uma incidência relatada de 5\% e distúrbios do esfíncter. A dor melhora quando se deita e aumenta com a carga. Os tratamentos variam de conservador a cirúrgico. Os diferentes tratamentos foram comparados, sendo o mais conservador o qual apresenta maior morbidade, pois predispõe complicações (pneumonia, embolia pulmonar, trombose venosa profunda, insuficiência cardíaca, úlceras por decúbito) e o intervencionista apresenta uma rápida melhora da atividade normal desses pacientes, as complicações são menores e a melhora da dor é notável e muito mais rápida. Conclusão: Fraturas devido a insuficiência pélvica ainda são pouco diagnosticadas. No entanto, já existem técnicas melhores de imagem e, combinadas com boa exploração e história clínica, podemos suspeitar dessa enfermidade e oferecer o melhor tratamento possivel, sendo os invasivos que tiveram melhores resultados, com menor morbidade e recuperação das atividades mais rapidamente. Nível de Evidência III; Revisão de estudos terapêuticos - Inquérito aos resultados do tratamento.

Descritores: Fractura; Pelve; Diagnóstico; Terapêutica.

\section{RESUMEN}

Objetivo: Las fracturas por insuficiencia pélvica son frecuentemente ignoradas en las personas de tercera edad y otros grupos de riesgo con dolor lumbar y pélvico después de un trauma de baja energía. La importancia de las fracturas sacras fue recientemente reconocida. El diagnóstico es difícil, tanto por clínica y de imagen, pero hay más opciones para el diagnóstico amplio. Métodos: Se realizó una revisión de la literatura sobre el diagnóstico y los tratamientos ofrecidos y cuál fue el que tuvo el mejor resultado. Resultados: Los pacientes con insuficiencia pélvica presentan movilidad limitada debido al dolor lumbar o pélvico. Neurologicamente estables, radiculopatia con incidencia del $5 \%$ y transtornos en los esfinteres. El dolor mejora al acostarse y aumenta con la carga. Los tratamientos varían de conservador y quirúrgico. Fue realizada la comparación entre los diferentes tratamientos, siendo que el que tiene más morbilidad es el conservador, ya que nos predispone a complicaciones (neumonía, embolia pulmonar, trombosis venosa profunda, insuficiencia cardíaca, úlceras por decúbito), y en los intervencionistas se encuentra una rápida mejora de la actividad normal de esos pacientes, las complicaciones son

Study conducted at the Centro Medico Puerta de Hierro, Zapopan, Jalisco.

Correspondence: Dirección: Boulevard Puerta de Hierro \#5150. Planta Baja.Torre C. Fracc. Puerta de Hierro C.P. 45116, Zapopan, Jalisco. dr.fcosanchez@gmail.com 
menores y la mejoría del dolor es notable y mucho más rápida. Conclusión: Las fracturas debido a la insuficiencia pélvica aún son poco diagnosticadas. Sin embargo, ya existen mejores técnicas de imagen y combinadas con buena exploración e historia clínica, podemos sospechar de esa entidad y ofrecer el mejor tratamiento posible, siendo estos los invasivos que tuvieron mejores resultados con menor morbilidad y recuperación de la actividad más rápidamente. Nivel de Evidencia III; Revisión de estudios terapéuticos -Investigación de los resultados de tratamiento.

Descriptores: Fractura; Pelvis; Diagnóstico; Terapéutica.

\section{INTRODUCTION}

Back pain is common in elderly patients, but it can be difficult to determine its cause. Vertebral fractures are a well-known cause, but the importance of sacral fractures has only been recognized recently. ${ }^{1} \mathrm{Sa}-$ cral insufficiency fractures (SIF) were first described by Lourie in $1982{ }^{2}{ }^{2}$

Pelvic insufficiency fractures (PIF) are often overlooked in the elderly and in other groups at risk for structurally weakened bones with back and pelvic pain after zero- or low-energy trauma. They are difficult to diagnose at an early stage because there is usually no significant history of trauma, they are often accompanied by concurrent degenerative lower lumbar pathology, and routine radiographs of the sacrum do not adequately show them.

The exact incidence of sacral insufficiency fractures is not known. However, it is thought that the potential prevalence of sacral insufficiency fractures in higher than widely accepted and that sacral insufficiency fractures continue to be widely ignored as a cause of pain and disability in the elderly and in other risk populations. ${ }^{3}$ The exact incidence of SIF is still unknown, but it has been reported to be between $1.0 \%$ and $1.8 \%$ among populations of patients at risk. SIF, in particular, is often overlooked in X-rays because the dislocation is minimal. ${ }^{4}$

Patients undergoing radiation therapy for the treatment of malignant tumors may be at special risk of SIF, with a prevalence of $89 \%$ in patients submitted to radiotherapy for cervical cancer. Elderly women with osteoporosis are also at high risk. Additionally, rheumatoid arthritis, Paget's disease, renal osteodystrophy, and hyperparathyroidism have been reported as risk factors. Sacral stress fractures have been occasionally reported during the last trimester of pregnancy and the early postpartum period. While previous trauma may be reported, it is generally minor and often completely absent. ${ }^{5}$

\section{METHODS}

We conducted a bibliographical review of articles, including reviews, meta-analyses, clinical trials, and even case presentations dedicated to this condition, in which we looked for timely diagnosis, as well as the different methods for it. We compared the bibliography entries in order to discuss which of the methods or combination of methods would be the best to reach a diagnosis or to clinically arrive at a frank diagnostic suspicion or if it is necessary to request a differential diagnosis. The bibliography was also reviewed for the different treatments specifically focused on this pathology since it was first described, both conservative and interventional, and we compared those results to be able to conduct a detailed discussion and thus reach a conclusion.

\section{RESULTS}

Reviewing the different articles that speak extensively about this pathology, we were able to observe that in various articles the most frequently mentioned comorbidities associated with a higher percentage of SIF were osteoporosis, hypertension, diabetes, vitamin $D$ deficiency, hypocalcemia, and nicotine abuse and the most often referenced complications of this condition were, in order of frequency, urinary tract infection, moderate pneumonia, depression, and thromboembolic events.

The clinical profile shown in the initial symptoms of SIF included low back pain, gluteal pain, and coxalgia. The delay observed between the first visit and an accurate diagnosis of SIF was 23.9 days on average in some studies and others reported figures of up to 90 days or more.
The patients with SIF or suspected SIF underwent additional imaging exams when radiography was not conclusive. Tomography was performed and showed traces of fractures in the sacrum and iliac bones, and also in the ischiopubic ramus. (Figure 1) Magnetic resonance was performed, directed at the lumbar spine due to the symptoms, revealing a hypointense signal in $\mathrm{T} 1$ and $\mathrm{T} 2$ sequences and hyperintense signal in the STIR sequence (Gold Standard). (Figure 2)

Other authors mention performing bone scintigraphy which can show zones of hyper-uptake in the sacral or pelvic regions in one or several foci, as the case may be, and it is rarely used as an auxiliary diagnostic to rule out a tumor. (Figure 3)

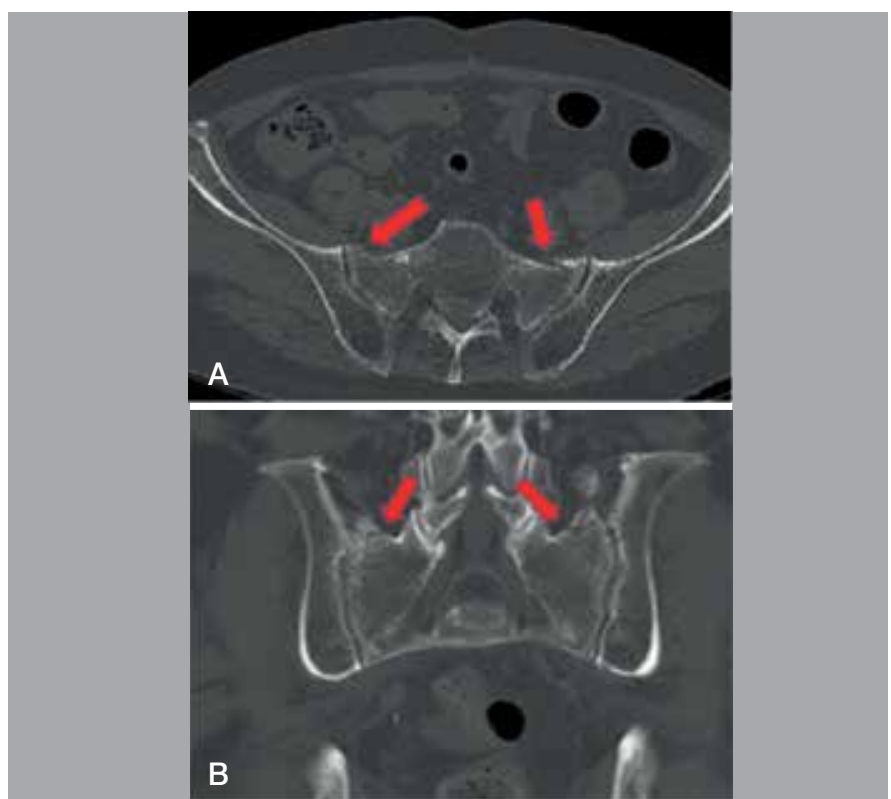

Figure 1. Computed tomography in patients with sacral insufficiency fractures. A. Axial; B. Coronal. ${ }^{4}$
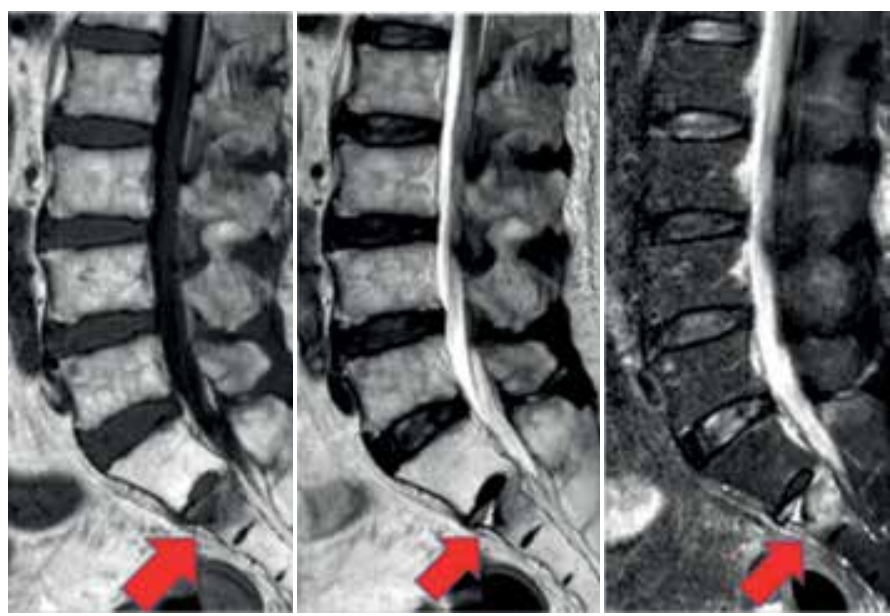

Figure 2. Magnetic resonance of the lumbar spine in patients with sacral insufficiency fracture. Neither stenosis nor compression fracture of the vertebral body is present, however changes are observed in the second sacral segment, hyperintense in T1 and hypointense in STIR and T2. ${ }^{4}$ 


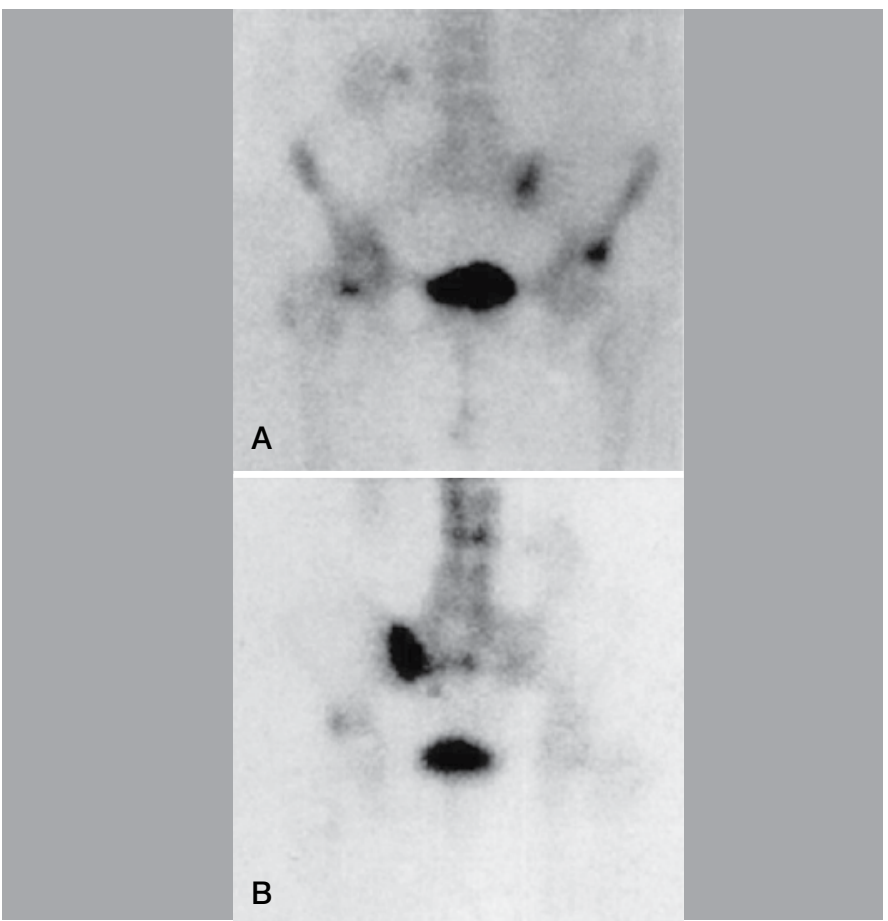

Figure 3. Bone scintigraphy a) Anterior b) Posterior. Unilateral fracture of the sacrum associated with fracture of the right femoral neck and the left ilium.

When we reviewed the treatment section, we found several alternatives. The one that predominated in various articles was conservative treatment with immobilization and pharmacotherapy for pain and osteoporosis, which can vary in terms of duration and complications and lead to an increase in other comorbidities as a result of immobilization and only brings clinical improvement in the long term. Some authors mention conservative treatment accompanied by teriparatide, which, according to the authors, has been well-accepted by patients and has had a positive effect in terms of improvement of the fracture and, more importantly, on the symptomology of the patient, specifically on pain. However, it is still widely discussed due to complications and given that it requires a long immobilization period that ranges from 6 to 8 weeks or longer, it is a period of high morbidity and mortality due to the state of rest of the patient, causing complications such as urinary tract infections, pneumonia, depression, decubitus ulcers, and thromboembolic events, as previously mentioned.

Given its rapid analgesic effect and positive impact on mobility and daily living activities, the recently accepted alternative is sacroplasty. This therapeutic option should be considered after a fruitless attempt at conservative treatment with persistent disabling pain. Because of their positive effect on pain and activity within the first four weeks, both the options of balloon sacroplasty and cement placement alone in the fractured area have had good outcomes in the articles consulted. The main complication presented is leakage of the cement, which is asymptomatic in most patients, although they do experience pain during the injection of the cement.

Another equally important therapeutic option is osteosynthesis, which is controversial given that most patients with SIF have osteoporosis and others have osteopenia. The articles analyzed that discuss this option, which are far fewer than those that discuss sacroplasty, report that it has been shown that percutaneous fixation with sacroiliac screws (Figure 4$)^{6}$ in selected patients allows direct primary healing of these fractures and early rehabilitation. There are very few articles that support this treatment, but those that do (Figure 5$)^{7}$ report a broadly satisfactory evolution in terms of preand postoperative and long-term pain, taking the position that the surgeon must have experience in this type of fixation to improve surgical time. There are fewer complications and only the possibility of nerve root damage is discussed.
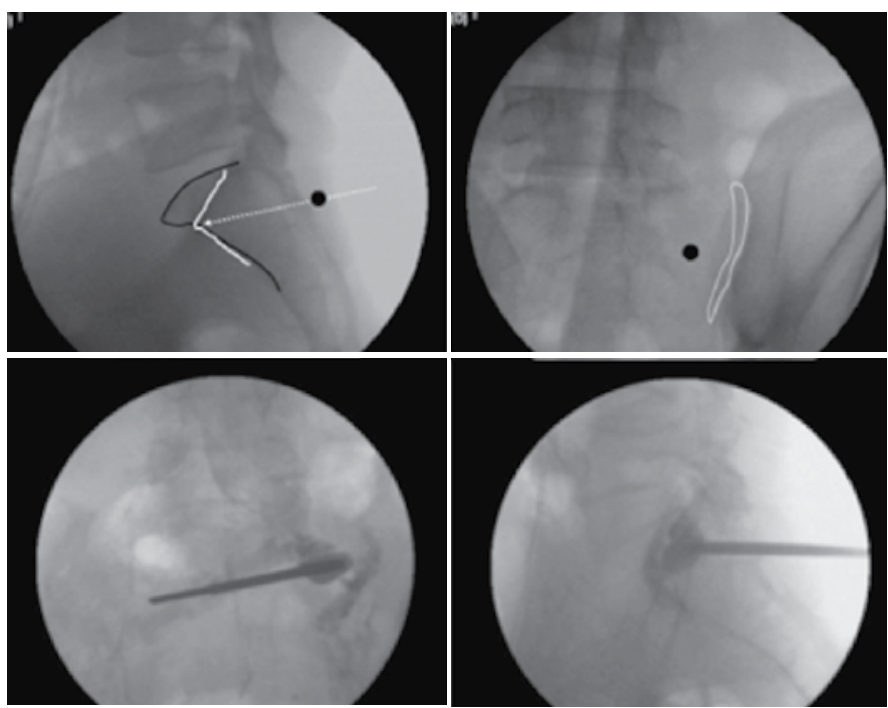

Figure 4. Intraoperative radiography 1 ) that shows the margin of the sacra body (black line) and the margin of the ala (white line). The entry point is the inferior lateral margin of the S1 pedicle (black circle) and the needle is inserted parallel to the superior terminal plate of S1 (white dotted line). Oblique contralateral radiograph 2) that shows the $\mathrm{S} 1$ ipsilateral joint space (white line). Anteroposterior 3) and lateral 4) radiographs that show the polymethylmethacrylate cement in the sacral wing without leakage. ${ }^{6}$

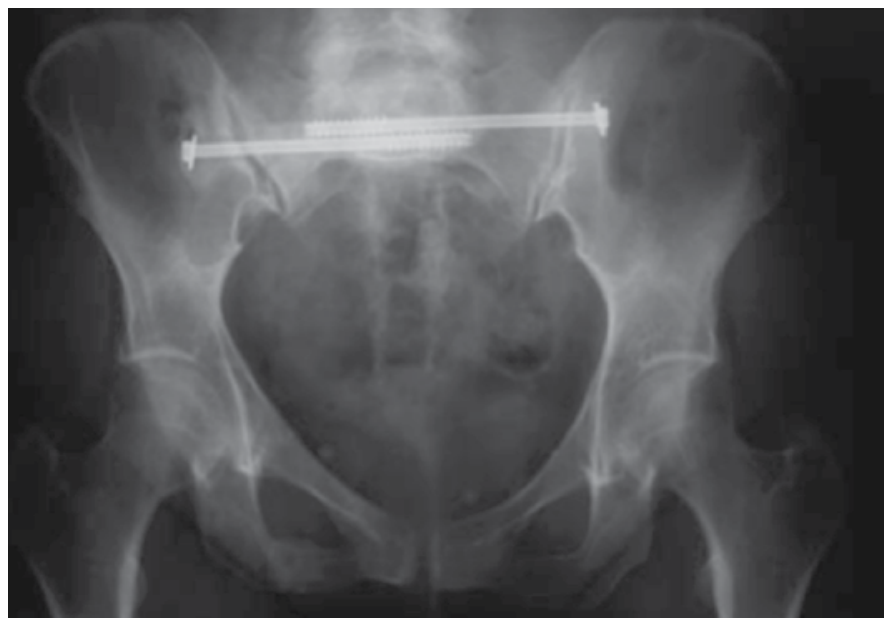

Figure 5. Postoperative radiograph that shows bilateral sacroiliac screws and consolidation of the fracture of the pubis. ${ }^{7}$

\section{DISCUSSION}

After the review of the articles several pending questions remain: How to be certain about a clinical diagnosis? Which treatment alternative if the best for this condition? What integrated treatment would be the most recommended for patients with SIF? How can fracture injuries be prevented in the population with osteopenia or osteoporosis? Conservative or interventional treatment? Do anti-osteoporosis medications really help? Although there are several questions, we know of various diagnostic options, such as radiography, and if that is not sufficient, thanks to technology we have auxiliary imaging studies such as bone scintigraphy, magnetic resonance (Gold Standard), and tomography, upon which we base our possible treatment for a faster recovery. We want to keep the patient immobilized for the least possible time and to recover their active lifestyle as soon as possible to prevent the possible complications that are widely mentioned in the results. We have to have a large multidisciplinary team with orthopedists, radiologists, interventional radiologists, nutritionists, geriatricians, and endocrinologists to achieve success 
effectively in the treatment of this condition. We must always keep it in mind when treating an elderly patient with low back, buttocks, or hip pain so it does not become a condition that is overlooked, which is what we noted in the reviewed articles. We must be thorough in both interrogation and physical examination to make sure that no piece of data that might guide us with this condition escapes.

\section{CONCLUSIONS}

From the information that was obtained and discussed, we can firmly conclude that clinical studies with large case series are needed. These will certainly lead us to the certainty that the patient needs more studies for their diagnosis and to determine the ideal treatment, whether it is conservative with adjuvants to fight osteoporosis and osteopenia or interventional, in which case to define which patients are ideal for sacroplasty or which patients are suitable for treatment with osteosynthesis. It is of utmost importance to continue the research and for spine surgery specialists to always consider the possibility of this condition in our elderly patients.

\section{ACKNOWLEDGEMENTS}

My special thanks to my patients who trusted me to solve, diagnose, and treat their condition,

To the Reespalda Association for their support in this training.

All authors declare no potential conflict of interest related to this article.

CONTRIBUTION OF THE AUTHORS: Each author made significant individual contributions to this manuscript. SFJ (0000-0003-2033-9688) EHJA $(0000-0001-9707-1208)^{\star}$, and DHM (0000-0002-8687-5830)* participated actively in the discussion of the results. DHM and EHJA reviewed and approved the final version of the article. SFJ performed the bibliographical research and wrote the article. SFJ, EHJA, and DHM contributed to the intellectual concept of the study. *ORCID (Open Researcher and Contributor ID).

\section{REFERENCES}

1. Gotis-Graham I, McGuigan L, DiamondT, Portek I, Quinn R, Sturgess A, et al. Sacral insufficiency fractures in the elderly. J Bone Joint Surg Br. 1994;76(6):882-6.

2. Garcia MC, Sánchez MTG, Carpintero RL. Fracturas de sacro por insuficiencia como causa poco conocida de dolor lumbar bajo. Exposición de cinco casos Sacral insufficienty fractures as a little known cause of low back pain. Five cases reports. Rev S. And. Traum. y Ort. 2015;33(2/2):79-87.

3. Lee YJ, Bong HJ, Kim JT, Chung DS. Sacral Insufficiency Fracture, Usually Overlooked Cause of Lumbosacral Pain. J Korean Neurosurg Soc. 2008;44(3):166-9.

4. Tamaki Y, Nagamachi A, Inoue K, Takeuchi M, Sugiura K, Omichi Y, et al. Incidence and clinical features of sacral insuf fi ciency fracture in the emergency department. Am J Emerg Med. 2017;35(9):1314-6.

5. Baldwin JM, Tucker L. Sacral insufficiency fractures : a case of mistaken identity. Int Med Case Rep J. 2014;7:93-8.

6. Choi KC, Shin SH, Lee DC, Shim HK, Park CK. Effects of Percutaneous Sacroplasty on Pain and Mobility in Sacral Insufficiency Fracture. J Korean Neurosurg Soc. 2017;60(1):60-6.

7. Tsiridis E, Upadhyay N, Gamie Z, Giannoudis PV. Percutaneous screw fixation for sacral insufficiency fractures: a review of three cases. J Bone and Joint Surgery. 2007;89(12):1650-3. 